Research Square

\title{
Effect of surgical sympathectomy in patients diagnosed with Thromboangiitis obliterans (TAO) compared to pharmacotherapy and bypass surgery.
}

Seyed Amir Miratashi Yazdi ( $\square$ amiratashi@sina.tums.ac.ir)

Tehran University of Medical Sciences

Javad Salimi

Tehran University of Medical Sciences

Fatemeh Chinisaz

Tehran University of Medical Sciences

Research Article

Keywords: surgical sympathectomy, bypass surgery, ILOPROST, Thromboangiitis obliterans (TAO), Buerger disease

Posted Date: February 24th, 2022

DOI: https://doi.org/10.21203/rs.3.rs-1332733/v1

License: (1) This work is licensed under a Creative Commons Attribution 4.0 International License. Read Full License 


\section{Abstract}

Background: Thromboangiitis obliterans (TAO) is a type of vasculopathy that affects small and intermediate vessels of extremities. Common symptoms are intermittent claudication, rest pain, Raynaud phenomenon, ischemic ulcers, superficial thrombophlebitis. Therapeutic interventions include vasodilators, prostaglandin analogues (ILOPROST), antiplatelets, surgical sympathectomy and bypass surgery.

Objectives: This prospective cohort study aimed to compare post-operative outcomes in patients with TAO that underwent surgical sympathectomy versus bypass surgery and pharmacotherapy.

Method :70 patients diagnosed with TAO were enrolled for the study. 37 patients with surgical sympathectomy, 11 patients with amputation surgery, 15 patients with bypass surgery and 12 patients who received ILOPROST were evaluated in first day, 3 months, and 6 months follow up. Improvements of common complaints were recorded and the final results were compared.

Result: Quit consumption of tobacco in any form is the fundamental treatment for Buerger disease, surgical sympathectomy and bypass surgery are helpful in patients with persistent pain and non-healing ischemic lesions that have abstained from consumption of tobacco. The final results showed that post-operative outcomes of patients underwent bypass surgery were significantly better than patients underwent sympathectomy and pharmacotherapy.

Conclusion: Patients with TAO that suffer from severe symptoms, significantly benefit from Bypass surgery in short-term follow up but because of lack of proper runoff arteries and the nature of the occlusive thrombi, which are diffuse and mostly located in distal vessels, bypass surgery is often feasible and sympathectomy commonly are performed. pharmacotherapy with different medications can improve the symptoms but have no effects on preventing the disease from progression.

\section{Introduction}

Burger disease or Thromboangiitis obliterans (TAO) is a type of vasculitis leading to cell-rich thrombus and vessel occlusion that affects mostly small and medium-sized arteries and veins in upper and lower limbs in young smoker men.

Thrombus formation in TAO follows a diffuse segmental pattern and despite the inflammatory nature of the disease, the vascular wall structure, and elastic lamina remain intact.

Etiology of the disease is still unknown, and tobacco consumption in any form is the major risk factor of the disease. Coagulopathies, immune deficiencies, dysfunction of the endothelial layer may play an important role in the initiation of TAO in some patients.

This disease manifests as vascular insufficiency such as intermittent claudication, rest pain, Raynaud phenomenon, ischemic ulcers, superficial thrombophlebitis.(1)

TAO is a multifactorial disease which is influenced by both genetic background and environmental factors. Various studies reported the association between TAO and different HLA alleles. High frequency of the , DRB1*04 , DRB1*16:01, $A^{\star} 03: 01$ and $A * 29: 01$, and the low frequency of the DRB1*01:01 alleles have been reported in Iranian population with TAO.(2)

As There are no specific angiographic findings, laboratory tests, and any positive serologic markers to diagnose TAO, diagnosis is made on the basis of the patients' symptoms and clinical data.

Although many diagnostic criteria have been proposed over the years, there are no complete and specific diagnostic criteria for the TAO.

The traditional criteria of Shionoya is the most used diagnostic criteria which includes: history of tobacco or cigarette consumption, infrapopliteal vascular involvements or upper limb involvements or migrans phlebitis, the onset of the symptoms before the age of 50 , and absence of risk factors for atherosclerotic disease.

other diagnostic interventions such as angiography may help confirm the disease(3)

A study by salami et al proposed a diagnostic criteria with $95.1 \%$ sensitivity and $78.7 \%$ specificity that compared to Papa diagnostic criteria had better efficacy especially in Iranian population.(4)

The therapeutic approaches for TAO are pharmacological therapy or surgical therapy, or even both.

Surgical sympathectomy and bypass are the most commonly performed surgical treatments.

Page 2/10 
Since there is no comprehensive and complete guideline for the treatment of TAO, it is not yet known which treatment is the best for reducing symptoms of the disease.

The aim of the study was to compare surgical sympathectomy outcomes with bypass surgery and conventional pharmacotherapy.

\section{Results}

70 patients with TAO were studied for 2 years and 6 months .69 of them were male (98/6\%) and one of them was female (1/4\%). The mean age of the patients was $43 / 24 \pm 9 / 8$.

Demographic data of the patients were recorded in Table 1.

The limb involvements in patients were as follows:

44 cases Left lower extremity (62/9\%), 45 cases right lower extremity (63/3\%), 13 cases left upper extremity (18/6\%), 16 cases right upper extremity $(22 / 9 \%)$.

Symptoms of TAO that patients presented with were as follows:

claudication of calf and sole were reported in 44 cases (62/9\%) and 40 cases (57/1\%) respectively.

50 patients had rest pain (71/4\%) and 46 patients had paresthesia (65/7\%).

6 patients (8/6\%) had, thrombo-phlebitis migrans,50 patients had gangrene (71/4\%), 56 patients had ulcers (80\%) and 17 patients had Raynaud phenomenon (24/3\%).

Therapeutic interventions on the patients were as follows:

37 patients (52/9\%) underwent sympathectomy surgery (28 patients underwent lumbar sympathectomy surgery, 9 patients underwent thoracic sympathectomy surgery ), 11 patients underwent amputation surgery(15/7\%), 15 patients underwent bypass surgery (21/4\%), ( femoro-peroneal bypass in 1 patient (1/4\%), left femoro-popliteal bypass in 2 patients (2/9\%), right femoro-popliteal bypass in 4 patients $(5 / 7 \%)$, anterior femoro-tibial bypass in 1 patient (1/4\%) aorto-femoral bypass in 4 patients (5/7\%), ilio-femoro-popliteal bypass in 1 patient ,left ilio-femoral bypass in 1 patient and iliopopliteal with sympathectomy in 1 patient)

12 patients $(17 / 1 \%)$ received ILOPROST drug.

Post-operative outcomes of the patients who underwent sympathectomy surgery, bypass surgery, and pharmacotherapy are listed in Table 2.

\section{Material And Method Study designs and patients:}

In this prospective cohort study,70 patients with TAO were considered for the evaluation.

The protocol of the study was approved by the review board of Tehran University of Medical Sciences and it was according to Helsinki ethical code and its later amendments. Patients gave written informed consent before any participation in the study.

Inclusion criteria compromised: all patients diagnosed with TAO that admitted to Sina hospital for therapeutic interventions within 2 years and 6 months.

Demographic parameters including sex, age, occupation, smoking were taken by a designed questionnaire; Also, history of previous interventions, including echocardiography, angiography, hemostasis tests, and history of previous therapeutic interventions, including drug therapy and surgical therapy, were recorded too.

The patients were evaluated one day, three months, and six months after sympathectomy surgery, bypass surgery, and pharmacotherapy.

\section{MISSING DATA :}


6 patients were out of reach for the follow-ups and were excluded. One patient did not accept any therapeutic intervention and one patient was expired 3 months after surgery and was excluded.

\section{Outcome measures}

Data associated with Symptoms of the disease including claudication of calves and soles, rest pain, paresthesia, thrombophlebitis migrans, gangrene, scars, Raynaud's phenomenon, and duration of the symptoms were collected through a well-validated questionnaire before the interventions and one day, three months and six months after the interventions and the improvements of patients' symptoms were compared.

The data were collected through phone calls in post-operative 3 and 6 month follow-ups.

\section{Statistical analysis}

All The data were analyzed by SPSS version 23.5 for windows.

\section{Results}

70 patients with TAO were studied for 2 years and 6 months .69 of them were male (98/6\%) and one of them was female (1/4\%). The mean age of the patients was $43 / 24 \pm 9 / 8$.

Demographic data of the patients were recorded in table 1.

The limb involvements in patients were as follows:

44 cases Left lower extremity (62/9\%), 45 cases right lower extremity (63/3\%), 13 cases left upper extremity (18/6 \%), 16 cases right upper extremity (22/9\%).

Symptoms of TAO that patients presented with were as follows:

claudication of calf and sole were reported in 44 cases (62/9\%) and 40 cases (57/1\%) respectively.

50 patients had rest pain (71/4\%) and 46 patients had paresthesia (65/7\%).

6 patients (8/6\%) had, thrombo-phlebitis migrans,50 patients had gangrene (71/4\%), 56 patients had ulcers ( $80 \%)$ and 17 patients had Raynaud phenomenon (24/3\%).

Therapeutic interventions on the patients were as follows:

37 patients (52/9\%) underwent sympathectomy surgery (28 patients underwent lumbar sympathectomy surgery, 9 patients underwent thoracic sympathectomy surgery ), 11 patients underwent amputation surgery(15/7\%), 15 patients underwent bypass surgery (21/4\%), ( femoro-peroneal bypass in 1 patient (1/4\%), left femoro-popliteal bypass in 2 patients (2/9\%), right femoro-popliteal bypass in 4 patients (5/7\%), anterior femoro-tibial bypass in 1 patient (1/4\%) aorto-femoral bypass in 4 patients (5/7\%), ilio-femoro-popliteal bypass in 1 patient ,left ilio-femoral bypass in 1 patient and iliopopliteal with sympathectomy in 1 patient)

12 patients (17/1\%) received ILOPROST drug.

Post-operative outcomes of the patients who underwent sympathectomy surgery, bypass surgery, and pharmacotherapy are listed in table 2.

\section{Discussion}

There are various therapeutic options for TAO which are pharmacotherapy with diverse medications (prostacyclin analog (iloprost and clinprost), aspirin, prostaglandin analog, folic acid cilostazol, clopidogrel, pentoxifylline )(5)

autologous bone marrow mononuclear cell (BM-MNC) implantation, implantation of spinal cord stimulators, Gene therapy with vascular endothelial growth factor, and surgical interventions, that include surgical sympathectomy, bypass surgery, and amputation of the involved 
limb in refractory TAO.

The study aimed to compare sympathectomy surgery outcomes in patients with TAO with bypass surgery and drug therapy outcomes.

Quit consumption of cigarettes and tobacco in any form is the only fundamental treatment for Buerger disease, and all the other surgical and medical treatments are palliatives. Many studies showed that there was no need for amputation surgery in patients with TAO that abstained from tobacco and cigarette as long as the organ was not ischemic or gangrenous.

Thus the results of the studies strongly prove the correlation between tobacco use and exacerbation of the disease leading to non-healing ulcers and limb amputation. $(1,6)$

However, it seems that discontinuing smoking on its own is not enough for treatment of the patients with critical limb ischemia and other therapeutic interventions are needed as well.(7)

Pharmacotherapy with different medications may help patients reduce ischemic ulcers and rest pain but have no effects on preventing the disease progression.

Surgical sympathectomy reduces spasms of arteries in patients with TAO, but it is still unclear how the surgery improves the symptoms.

It seems that surgical sympathectomy is helpful in patients with persistent pain and non-healing ischemic lesions that have abstained from consumption of tobacco.(8)

In our study, Among 70 patients, 28 of them underwent lumbar sympathectomy, and 9 of them underwent thoracic sympathectomy. one day after surgery, around $60 \%$ of patients had improvements of claudication of calf, paresthesia, and rest pain.

In 3-month post-operative follow-ups ,50-60\% of patients mentioned improvements and remissions in symptoms, and in 6-moth post-op follow-ups the patients mentioned $50-60 \%$ remission in symptoms (detailed reports are in Table 2 )

The efficacy of sympathectomy in short-term follow-ups was evaluated in a study done by N.Nakajima, and results were as follows: $60 \%$ of all patients showed marked improvements in symptoms. $25 \%$ of them improved in symptoms and only $1 / 5 \%$ had aggravation in symptoms .The study also confirmed that advanced symptoms such as rest pain and ulcers were improved after sympathectomy too.

remission in symptoms in long-term follow-ups were recorded in $83 \%$ of patients in which the effectiveness of the surgery lasted in $50 \%$ of them after 5 years and just $10 \%$ of the patients had no change in symptoms.(9)

Although surgical sympathectomy improves severe symptoms in patients, complete remission only occurs if they stop smoking. Stop smoking can heal ischemic lesions and reduce the risk of amputation.(6)

The correlation between recovery rate in people who quit smoking and continue smoking after sympathectomy is detailed in Table 3 .

Among 70 patients, 15 of them underwent bypass surgery. In 6-month follow-ups, no treatment failure was reported. Moreover, improvements of symptoms in one-day,3-month, and 6-month follow-ups were significant.

Improvements and remission of the symptoms were around 70 to $80 \%$.

The results were much better than outcomes in patients who underwent sympathectomy surgery and pharmacotherapy.

A study done by Dilege and colleagues on 27 patients who underwent bypass surgery confirmed successful bypasses with a $92.5 \%$ salvage rate in follow-ups in 3 years. Also, 31 patients underwent bypass surgery in a study done by Ohta and the post-op results of the study showed an $85.4 \%$ salvage rate in 10-year follow-ups.

However, bypass surgery seems to be a beneficial surgical treatment with a high amputation-free survival rate, this procedure is most of the time difficult and unavailable due to lack of possible, sufficient vessel and diffuse segmental pattern of thrombus in distal vessels.

Surgical sympathectomy usually is performed when bypass surgery is impossible.(10)

Among 70 patients, 12 of them underwent pharmacotherapy and received lloprost, a. Detailed report of post-ups follow ups mentioned in Table 2. 
To clarify which performed therapeutic intervention, is the most appropriate treatment, we compared the sympathectomy surgery, bypass surgery and pharmacotherapy based on the rate of improvements of claudication of calf, ulcer

, rest pain, plantar claudication in post-op follow-ups and P-value was calculated. (Table 4, Table 5)

According to the results of comparison between sympathectomy and bypass, it seems that patients benefited significantly more from bypass surgery than sympathectom; However, there was no meaningful results of comparison between sympathectomy and pharmacotherapy.

However, a randomized controlled study that compared sympathectomy with ILOPROST showed that ILOPROST is more effective in healing of ulcers and rest pain in patients with TAO.(11)

\section{Conclusion}

The only very effective and fundamental treatment of TAO is tobacco and cigarette cessation.

However, patients with advanced and severe symptoms such as rest pain, ulcers and gangrenes need invasive therapeutic interventions to reduce the symptoms and discontinuing tobacco consumption is not sufficient on its own.

Surgical sympathectomy, and bypass surgery are the most common surgical treatments for the TAO. Sympathectomy is usually useful in decreasing the symptoms such as rest pain and ischemic ulcers; However patients in our study significantly benefited more from bypass surgery than sympathectomy and pharmacotherapy, but due to lack of proper arteries for autologous graft and nature of the occlusive thrombus, which are diffuse and mostly located in distal vessels, $(6,10)$ bypass surgery is often feasible and sympathectomy commonly are performed.

Although several articles, including our study, confirmed that patients benefit from bypass surgery in short-term follow-ups, according to recent studies, long-term outcomes are not satisfactory(1) One main reason that long-term outcomes of bypass surgery is not very good seems to be that patients start smoking after a while which causes TAO to reactivate.

The correlation between recovery rate in people who quit smoking and continue smoking after bypass surgery is detailed in Table 6 .

In a study done by Ohta et al ,31 patients underwent bypass surgery. Primary graft patency was $41 \%$ at 1 year after operation, $32 \%$ at 5 years, and $30 \%$ at 10 years. Secondary graft patency was $54 \%$ at 1 year of follow-up, $47 \%$ at 5 years, and $39 \%$ at 10 years. (12)

Unfortunately, very limited studies have evaluated treatment approaches of Buerger disease and due to lack of any accurate protocol for treatment of TAO and low prevalence of the disease, it is not possible to make a definite and comprehensive conclusion about which therapeutic interventions are the most effective

\section{Declarations}

\section{Availability of Data and Materials}

The datasets used and analyzed during the current study available from the corresponding author on request.

\section{References}

1. Olin JW. Thromboangiitis obliterans (Buerger's disease). Peripheral arterial disease. 2003:303-18.

2. Dehghani Firouzabadi F, Salimi J, Amirzargar A, Dehghani Firouzabadi M, Arbabi H, Mousavizadeh SM, et al. Human leukocyte antigen class I (A, B) and class II (DRB1) allele and haplotype frequencies in Iranian patients with Buerger's disease. Immunity, Inflammation and Disease. 2020;8(3):434-40.

3. Lazarides M, Georgiadis G, Papas T, Nikolopoulos E. Diagnostic criteria and treatment of Buerger's disease: a review. The international journal of lower extremity wounds. 2006;5(2):89-95.

4. Ramin M, Salimi J, Meysamie A. An Iranian scoring system for diagnosing Buerger's disease. Acta Medica Iranica. 2014:60-5.

5. Cacione DG, Baptista-Silva JC, Macedo CR. Pharmacological treatment for Buerger's disease. Cochrane Database of Systematic Reviews. 2016(2). 
6. Ates A, Yekeler I, Ceviz M, Erkut B, Pac M, Basoglu A, et al. One of the most frequent vascular diseases in northeastern of Turkey: Thromboangiitis obliterans or Buerger's disease (experience with 344 cases). International journal of cardiology. 2006;111(1):147-53.

7. Fazeli B, Moghadam MD, Niroumand S. How to treat a patient with thromboangiitis obliterans: a systematic review. Annals of vascular surgery. 2018;49:219-28.

8. Mills Sr JL, editor Buerger's disease in the 21st century: diagnosis, clinical features, and therapy. Seminars in vascular surgery; 2003 : Elsevier.

9. Nakajima N. The change in concept and surgical treatment on Buerger's disease-personal experience and review. International journal of cardiology. 1998;66:S273-S80.

10. Ye K, Shi H, Qin J, Yin M, Liu X, Li W, et al. Outcomes of endovascular recanalization versus autogenous venous bypass for thromboangiitis obliterans patients with critical limb ischemia due to tibioperoneal arterial occlusion. Journal of vascular surgery. 2017;66(4):1133-42. e1.

11. Cacione DG, Moreno DH, Nakano LC, Baptista-Silva JC. Surgical sympathectomy for Buerger's disease. JRSM open. 2017;8(8):2054270417717666.

12. Ohta T, Ishioashi H, Hosaka M, Sugimoto I. Clinical and social consequences of Buerger disease. Journal of vascular surgery. 2004;39(1):176-80.

\section{Tables}

Table 1

:Demographic data of the patients

\begin{tabular}{|ll|}
\hline Variable & percentage \\
\hline Age & $43 / 24 \pm 9 / 8$ \\
\hline Male female ratio & $70 / 42 \%$ \\
\hline Calf claudication & $62 / 9 \%$ \\
\hline Plantar Claudication & $57 / 1 \%$ \\
\hline Rest pain & $71 / 4 \%$ \\
\hline paresthesia & $65 / 7 \%$ \\
\hline thrombo-phlebitis migrans & $8 / 6 \%$ \\
\hline Gangrene & $71 / 4 \%$ \\
\hline Ulcer & $80 \%$ \\
\hline Raynaud & $24 / 3 \%$ \\
\hline
\end{tabular}


Table 2

Post-operative improvements of symptoms in patients underwent sympathectomy, bypass surgery and pharmacotherapy

\begin{tabular}{|c|c|c|c|c|c|c|c|c|c|}
\hline & & $\begin{array}{l}\text { claudication } \\
\text { of calf }\end{array}$ & $\begin{array}{l}\text { Plantar } \\
\text { claudication }\end{array}$ & Paresthesia & $\begin{array}{l}\text { Migrans } \\
\text { phlebitis }\end{array}$ & Gangrene & Ulcer & $\begin{array}{l}\text { Rest } \\
\text { pain }\end{array}$ & Reynaud \\
\hline \multirow[t]{3}{*}{$\begin{array}{l}\text { Sympathectomy } \\
\text { Post-op } \\
\text { improvements }\end{array}$} & $\begin{array}{l}1 D^{*} \\
F / U^{*} S\end{array}$ & $\begin{array}{l}13 \text { Cases } \\
(61 / 9 \%)\end{array}$ & $\begin{array}{l}15 \text { Cases } \\
(52 / 6 \%)\end{array}$ & $\begin{array}{l}19 \text { Cases } \\
(65 / 5 \%)\end{array}$ & & & & $\begin{array}{l}18 \\
\text { Cases } \\
(64 / 3 \%)\end{array}$ & $\begin{array}{l}4 \text { Cases } \\
(50 \%)\end{array}$ \\
\hline & $\begin{array}{l}3 M^{*} \\
F / U^{*} S\end{array}$ & $\begin{array}{l}14 \text { Cases } \\
(60 / 9 \%)\end{array}$ & $\begin{array}{l}11 \text { Cases } \\
(50 \%)\end{array}$ & $\begin{array}{l}15 \text { Cases } \\
(53 / 6 \%)\end{array}$ & $\begin{array}{l}4 \text { Cases } \\
(80 \%)\end{array}$ & $\begin{array}{l}10 \text { Cases } \\
(55 / 6 \%)\end{array}$ & $\begin{array}{l}15 \\
\text { Cases } \\
(57 / 7 \%)\end{array}$ & $\begin{array}{l}15 \\
\text { Cases } \\
(51 / 7 \%)\end{array}$ & $\begin{array}{l}4 \text { Cases } \\
(50 \%)\end{array}$ \\
\hline & $\begin{array}{l}6 M^{*} \\
F / U^{*} S\end{array}$ & $\begin{array}{l}\text { 14Cases } \\
(53 / 8 \%)\end{array}$ & $\begin{array}{l}10 \text { Cases } \\
(43 / 5 \%)\end{array}$ & $\begin{array}{l}15 \text { Cases } \\
(53 / 6 \%)\end{array}$ & $\begin{array}{l}5 \text { Cases } \\
(83 / 3 \%)\end{array}$ & $\begin{array}{l}11 \text { Cases } \\
(55 \%)\end{array}$ & $\begin{array}{l}16 \\
\text { Cases } \\
(61 / 5 \%)\end{array}$ & $\begin{array}{l}19 \\
\text { Cases } \\
(61 / 3 \%)\end{array}$ & $\begin{array}{l}5 \text { Cases } \\
(62 / 5 \%)\end{array}$ \\
\hline \multirow{3}{*}{$\begin{array}{l}\text { Bypass surgery } \\
\text { post-op } \\
\text { improvements }\end{array}$} & $\begin{array}{l}1 D^{*} \\
F / U^{*} S\end{array}$ & $\begin{array}{l}8 \text { Cases } \\
(66 / 7 \%)\end{array}$ & $\begin{array}{l}8 \text { Cases } \\
(72 / 7 \%)\end{array}$ & $\begin{array}{l}8 \text { Cases } \\
(61 / 5 \%)\end{array}$ & & & & $\begin{array}{l}9 \text { Cases } \\
(75 \%)\end{array}$ & $\begin{array}{l}1 \text { Case } \\
(25 \%)\end{array}$ \\
\hline & $\begin{array}{l}3 M^{*} \\
F / U^{*} S\end{array}$ & $\begin{array}{l}8 \text { Cases } \\
(66 / 7 \%)\end{array}$ & $\begin{array}{l}8 \text { Cases } \\
(72 / 7 \%)\end{array}$ & $\begin{array}{l}9 \text { Cases } \\
(64 / 3 \%)\end{array}$ & & $\begin{array}{l}5 \text { Cases } \\
(62 / 5 \%)\end{array}$ & $\begin{array}{l}8 \text { Cases } \\
(66 / 7 \%)\end{array}$ & $\begin{array}{l}10 \\
\text { Cases } \\
(83 / 3 \%)\end{array}$ & (76/9\%) \\
\hline & $\begin{array}{l}6 \mathrm{M}^{*} \\
\mathrm{~F} / \mathrm{U}^{\star} \mathrm{S}\end{array}$ & $\begin{array}{l}9 \text { Cases } \\
(75 \%)\end{array}$ & $\begin{array}{l}9 \text { Cases } \\
(81 / 8 \%)\end{array}$ & $\begin{array}{l}10 \text { Cases } \\
(83 / 3 \%)\end{array}$ & $\begin{array}{l}2 \text { Cases } \\
(66 / 7 \%)\end{array}$ & $\begin{array}{l}7 \text { Cases } \\
(87 / 5 \%)\end{array}$ & $\begin{array}{l}10 \\
\text { Cases } \\
(83 / 3 \%)\end{array}$ & $\begin{array}{l}11 \\
\text { Cases } \\
(91 / 7 \%)\end{array}$ & $\begin{array}{l}3 \text { Cases } \\
(75 \%)\end{array}$ \\
\hline \multirow[t]{3}{*}{$\begin{array}{l}\text { Pharmacotherapy } \\
\text { improvements }\end{array}$} & $\begin{array}{l}1 D^{*} \\
F / U^{*} S\end{array}$ & $\begin{array}{l}\text { 1Case } \\
(100 \%)\end{array}$ & $\begin{array}{l}\text { 2Cases } \\
(100 \%)\end{array}$ & $\begin{array}{l}\text { 2Cases } \\
(100 \%)\end{array}$ & & $\begin{array}{l}1 \text { case } \\
(50 \%)\end{array}$ & $\begin{array}{l}1 \text { case } \\
(20 \%)\end{array}$ & $\begin{array}{l}\text { 1Case } \\
(25 \%)\end{array}$ & $\begin{array}{l}\text { 1Case } \\
(100 \%)\end{array}$ \\
\hline & $\begin{array}{l}3 M^{*} \\
F / U^{*} S\end{array}$ & $\begin{array}{l}\text { 1Case } \\
(100 \%)\end{array}$ & $\begin{array}{l}\text { 2Cases } \\
(100 \%)\end{array}$ & $\begin{array}{l}\text { 2Cases } \\
(100 \%)\end{array}$ & & $\begin{array}{l}\text { 2Cases } \\
(100 \%)\end{array}$ & $\begin{array}{l}\text { 2Cases } \\
(33 / 3 \%)\end{array}$ & $\begin{array}{l}\text { 1Case } \\
(25 \%)\end{array}$ & \\
\hline & $\begin{array}{l}6 M^{*} \\
F / U^{*} S\end{array}$ & $\begin{array}{l}\text { 1Case } \\
(100 \%)\end{array}$ & $\begin{array}{l}1 \text { Case } \\
(50 \%)\end{array}$ & $\begin{array}{l}\text { 3Cases } \\
(75 \%)\end{array}$ & & $\begin{array}{l}\text { 2Cases } \\
(66 / 7 \%)\end{array}$ & $\begin{array}{l}\text { 2Cases } \\
(33 / 3 \%)\end{array}$ & $\begin{array}{l}\text { 3Cases } \\
(60 \%)\end{array}$ & \\
\hline
\end{tabular}


Table 3

the correlation between recovery rate in people who quit smoking and continue smoking after sympathectomy .

\begin{tabular}{|c|c|c|c|c|c|c|c|c|c|}
\hline & symptoms & $\begin{array}{l}\text { Claudication } \\
\text { of calf }\end{array}$ & $\begin{array}{l}\text { Plantar } \\
\text { claudication }\end{array}$ & Paresthesia & $\begin{array}{l}\text { Migrans } \\
\text { phlebitis }\end{array}$ & Gangrene & Ulcer & $\begin{array}{l}\text { Rest } \\
\text { pain }\end{array}$ & $\begin{array}{l}\text { Raynaud } \\
\text { phenomenon }\end{array}$ \\
\hline $\begin{array}{l}1 D^{*} \\
\text { F/Us }\end{array}$ & $\begin{array}{l}\text { Smoking - } \\
\text { Improvements - }\end{array}$ & $\begin{array}{l}3 \text { Cases } \\
(42 / 9 \%)\end{array}$ & $\begin{array}{l}3 \text { Cases } \\
(50 \%)\end{array}$ & $\begin{array}{l}5 \text { Cases } \\
(45 / 5 \%)\end{array}$ & $\begin{array}{l}1 \text { Case } \\
(33 / 3 \%)\end{array}$ & $\begin{array}{l}3 \text { Cases } \\
(50 \%)\end{array}$ & $\begin{array}{l}5 \text { Cases } \\
(50 \%)\end{array}$ & $\begin{array}{l}4 \text { Cases } \\
(36 / 4 \%)\end{array}$ & $\begin{array}{l}3 \text { Cases } \\
(60 \%)\end{array}$ \\
\hline $\begin{array}{l}1 D^{*} \\
\text { F/Us }\end{array}$ & $\begin{array}{l}\text { Smoking - } \\
\text { Improvements } \\
+\end{array}$ & $\begin{array}{l}4 \text { Cases } \\
(57 / 1 \%)\end{array}$ & $\begin{array}{l}3 \text { Cases } \\
(50 \%)\end{array}$ & $\begin{array}{l}6 \text { Cases } \\
(54 / 5 \%)\end{array}$ & $\begin{array}{l}\text { 2Cases } \\
(66 / 7 \%)\end{array}$ & $\begin{array}{l}3 \text { Cases } \\
(50 \%)\end{array}$ & $\begin{array}{l}5 \text { Cases } \\
(50 \%)\end{array}$ & $\begin{array}{l}7 \text { Cases } \\
(63 / 6 \%)\end{array}$ & $\begin{array}{l}2 \text { Cases } \\
(40 \%)\end{array}$ \\
\hline $\begin{array}{l}1 D^{*} \\
\text { F/Us }\end{array}$ & $\begin{array}{l}\text { Smoking + } \\
\text { Improvements - }\end{array}$ & $\begin{array}{l}4 \text { Cases } \\
(40 \%)\end{array}$ & $\begin{array}{l}5 \text { Cases } \\
(45 / 5 \%)\end{array}$ & $\begin{array}{l}4 \text { Cases } \\
(28 / 6 \%)\end{array}$ & $(0 \%)$ & $\begin{array}{l}\text { 1 Cases } \\
(33 / 3 \%)\end{array}$ & $\begin{array}{l}3 \text { Cases } \\
(42 / 9 \%)\end{array}$ & $\begin{array}{l}3 \text { Cases } \\
(27 / 3 \%)\end{array}$ & $\begin{array}{l}\text { 1 Cases } \\
(33 / 3 \%)\end{array}$ \\
\hline $\begin{array}{l}1 D^{*} \\
\text { F/Us }\end{array}$ & $\begin{array}{l}\text { Smoking + } \\
\text { Improvements+ }\end{array}$ & $\begin{array}{l}6 \text { Cases } \\
(60 \%)\end{array}$ & $\begin{array}{l}6 \text { Cases } \\
(54 / 5 \%)\end{array}$ & $\begin{array}{l}10 \text { Cases } \\
(71 / 4 \%)\end{array}$ & $\begin{array}{l}2 \text { Cases } \\
(100 \%)\end{array}$ & $\begin{array}{l}2 \text { Cases } \\
(66 / 7 \%)\end{array}$ & $\begin{array}{l}4 \text { Cases } \\
(57 / 1 \%)\end{array}$ & $\begin{array}{l}8 \text { Cases } \\
(72 / 7 \%)\end{array}$ & $\begin{array}{l}2 \text { Cases } \\
(66 / 7 \%)\end{array}$ \\
\hline $\begin{array}{l}3 \mathrm{M}^{*} \\
\mathrm{~F} / \mathrm{Us}\end{array}$ & $\begin{array}{l}\text { Smoking - } \\
\text { Improvements - }\end{array}$ & $\begin{array}{l}2 \text { Cases } \\
(28 / 6 \%)\end{array}$ & $\begin{array}{l}3 \text { Cases } \\
(42 / 9 \%)\end{array}$ & $\begin{array}{l}5 \text { Cases } \\
(45 / 5 \%)\end{array}$ & $\begin{array}{l}1 \text { Case } \\
(33 / 3 \%)\end{array}$ & $\begin{array}{l}3 \text { Cases } \\
(33 / 3 \%)\end{array}$ & $\begin{array}{l}4 \text { Cases } \\
(36 / 4 \%)\end{array}$ & $\begin{array}{l}5 \text { Cases } \\
(41 / 7 \%)\end{array}$ & $\begin{array}{l}2 \text { Cases } \\
(40 \%)\end{array}$ \\
\hline $\begin{array}{l}3 \mathrm{M}^{*} \\
\mathrm{~F} / \mathrm{Us}^{-}\end{array}$ & $\begin{array}{l}\text { Smoking - } \\
\text { Improvements } \\
+\end{array}$ & $\begin{array}{l}5 \text { Cases } \\
(71 / 4 \%)\end{array}$ & $\begin{array}{l}4 \text { Cases } \\
(57 / 1 \%)\end{array}$ & $\begin{array}{l}6 \text { Cases } \\
(54 / 5 \%)\end{array}$ & $\begin{array}{l}2 \text { Cases } \\
(66 / 7 \%)\end{array}$ & $\begin{array}{l}6 \text { Cases } \\
(66 / 7 \%)\end{array}$ & $\begin{array}{l}7 \text { Cases } \\
(63 / 6 \%)\end{array}$ & $\begin{array}{l}7 \text { Cases } \\
(57 / 3 \%)\end{array}$ & $\begin{array}{l}3 \text { Cases } \\
(60 \%)\end{array}$ \\
\hline $\begin{array}{l}3 \mathrm{M}^{*} \\
\mathrm{~F} / \mathrm{Us}^{-}\end{array}$ & $\begin{array}{l}\text { Smoking + } \\
\text { Improvements - }\end{array}$ & $\begin{array}{l}6 \text { Cases } \\
(50 \%)\end{array}$ & $\begin{array}{l}7 \text { Cases } \\
(53 / 8 \%)\end{array}$ & $\begin{array}{l}7 \text { Cases } \\
(53 / 8 \%)\end{array}$ & $(0 \%)$ & $\begin{array}{l}3 \text { Cases } \\
(42 / 9 \%)\end{array}$ & $\begin{array}{l}6 \text { Cases } \\
(54 / 5 \%)\end{array}$ & $\begin{array}{l}6 \text { Cases } \\
(54 / 5 \%)\end{array}$ & $\begin{array}{l}1 \text { Cases } \\
(50 \%)\end{array}$ \\
\hline $\begin{array}{l}3 \mathrm{M}^{*} \\
\mathrm{~F} / \mathrm{Us}^{-}\end{array}$ & $\begin{array}{l}\text { Smoking + } \\
\text { Improvements+ }\end{array}$ & $\begin{array}{l}6 \text { Cases } \\
(50 \%)\end{array}$ & $\begin{array}{l}6 \text { Cases } \\
(46 / 2 \%)\end{array}$ & $\begin{array}{l}6 \text { Cases } \\
(46 / 2 \%)\end{array}$ & $\begin{array}{l}2 \text { Cases } \\
(100 \%)\end{array}$ & $\begin{array}{l}4 \text { Cases } \\
(57 / 1 \%)\end{array}$ & $\begin{array}{l}5 \text { Cases } \\
(45 / 5 \%)\end{array}$ & $\begin{array}{l}5 \text { Cases } \\
(45 / 5 \%)\end{array}$ & $\begin{array}{l}1 \text { Cases } \\
(50 \%)\end{array}$ \\
\hline $\begin{array}{l}6 \mathrm{M}^{*} \\
\mathrm{~F} / \mathrm{Us}\end{array}$ & $\begin{array}{l}\text { Smoking - } \\
\text { Improvements - }\end{array}$ & $\begin{array}{l}\text { 4Cases } \\
(50 \%)\end{array}$ & $\begin{array}{l}\text { 4Cases } \\
(57 / 1 \%)\end{array}$ & $\begin{array}{l}\text { 4Cases } \\
(36 / 4 \%)\end{array}$ & $\begin{array}{l}\text { 1Case } \\
(33 / 3 \%)\end{array}$ & $\begin{array}{l}2 \text { Cases } \\
(20 \%)\end{array}$ & $\begin{array}{l}3 \text { Cases } \\
(27 / 2 \%)\end{array}$ & $\begin{array}{l}3 \text { Cases } \\
(23 / 1 \%)\end{array}$ & $\begin{array}{l}\text { 1Case } \\
(25 \%)\end{array}$ \\
\hline $\begin{array}{l}6 \mathrm{M}^{*} \\
\mathrm{~F} / \mathrm{Us}^{\mathrm{s}}\end{array}$ & $\begin{array}{l}\text { Smoking - } \\
\text { Improvements } \\
+\end{array}$ & $\begin{array}{l}\text { 4Cases } \\
(50 \%)\end{array}$ & $\begin{array}{l}3 \text { Cases } \\
(42 / 9 \%)\end{array}$ & $\begin{array}{l}\text { 7Cases } \\
(63 / 6 \%)\end{array}$ & $\begin{array}{l}\text { 2Cases } \\
(63 / 7 \%)\end{array}$ & $\begin{array}{l}\text { 8Cases } \\
(80 \%)\end{array}$ & $\begin{array}{l}\text { 8Cases } \\
(72 / 8 \%)\end{array}$ & $\begin{array}{l}\text { 10Cases } \\
(76 / 9 \%)\end{array}$ & $\begin{array}{l}\text { 3Cases } \\
(75 \%)\end{array}$ \\
\hline $\begin{array}{l}6 \mathrm{M}^{*} \\
\mathrm{~F} / \mathrm{Us}\end{array}$ & $\begin{array}{l}\text { Smoking + } \\
\text { Improvements - }\end{array}$ & $\begin{array}{l}\text { 7Cases } \\
(50 \%)\end{array}$ & $\begin{array}{l}\text { 8Cases } \\
(57 / 1 \%)\end{array}$ & $\begin{array}{l}\text { 8Cases } \\
(61 / 5 \%)\end{array}$ & $(0 \%)$ & $\begin{array}{l}\text { 5Cases } \\
(62 / 5 \%)\end{array}$ & $\begin{array}{l}6 \text { Cases } \\
(54 / 5 \%)\end{array}$ & $\begin{array}{l}\text { 6Cases } \\
(50 \%)\end{array}$ & $\begin{array}{l}\text { 2Cases } \\
(50 \%)\end{array}$ \\
\hline $\begin{array}{l}6 \mathrm{M}^{*} \\
\mathrm{~F} / \mathrm{Us}^{-}\end{array}$ & $\begin{array}{l}\text { Smoking + } \\
\text { Improvements+ }\end{array}$ & $\begin{array}{l}\text { 7Cases } \\
(50 \%)\end{array}$ & $\begin{array}{l}\text { 6Cases } \\
(42 / 9 \%)\end{array}$ & $\begin{array}{l}\text { 5Cases } \\
(38 / 5 \%)\end{array}$ & $\begin{array}{l}\text { 3Cases } \\
(100 \%)\end{array}$ & $\begin{array}{l}\text { 3Cases } \\
(37 / 5 \%)\end{array}$ & $\begin{array}{l}\text { 5Cases } \\
(45 / 5 \%)\end{array}$ & $\begin{array}{l}\text { 6Cases } \\
(50 \%)\end{array}$ & $\begin{array}{l}\text { 2Cases } \\
(50 \%)\end{array}$ \\
\hline
\end{tabular}

Table 4

Comparison between post-sympathectomy recovery rate and post-bypass recovery

rate

\begin{tabular}{|llll|}
\hline Symptoms & $\begin{array}{l}\text { P-value } \\
\text { (1 day after surgery })\end{array}$ & $\begin{array}{l}\text { P-value } \\
\text { (3-month F/Us) }\end{array}$ & $\begin{array}{l}\text { P-value } \\
\text { (6-month F/Us) }\end{array}$ \\
\hline Claudication of calf & $<0 / 005$ & $<0 / 005$ & $0 / 003$ \\
\hline Ulcer & $0 / 028$ & $0 / 001$ & $0 / 005$ \\
\hline Rest pain & $0 / 001$ & $<0 / 005$ & $0 / 001$ \\
\hline Plantar claudication & $0 / 001$ & $0 / 001$ & $0 / 007$ \\
\hline
\end{tabular}


Table 5

Comparison between post-sympathectomy recovery rate and post-pharmacotherapy

\begin{tabular}{|llll|}
\hline \multicolumn{4}{c|}{ recovery rate } \\
\hline Symptoms & $\begin{array}{l}\text { P-value } \\
\text { (1 day after surgery) }\end{array}$ & $\begin{array}{l}\text { P-value } \\
\text { (3-month F/Us) }\end{array}$ & $\begin{array}{l}\text { P-value } \\
\text { (6-month F/Us) }\end{array}$ \\
\hline Claudication of calf & $0 / 125$ & $0 / 112$ & $0 / 127$ \\
\hline Ulcer & $0 / 064$ & $0 / 157$ & $0 / 087$ \\
\hline Rest pain & $0 / 098$ & $0 / 157$ & $0 / 03$ \\
\hline Plantar claudication & $0 / 089$ & $0 / 075$ & $0 / 176$ \\
\hline
\end{tabular}

Table 6

the correlation between recovery rate in people who quit smoking and continue smoking after bypass surgery .

\begin{tabular}{|c|c|c|c|c|c|c|c|c|c|}
\hline & symptoms & $\begin{array}{l}\text { Claudication } \\
\text { of calf }\end{array}$ & $\begin{array}{l}\text { Plantar } \\
\text { claudication }\end{array}$ & Paresthesia & $\begin{array}{l}\text { Migrans } \\
\text { phlebitis }\end{array}$ & Gangrene & Ulcer & $\begin{array}{l}\text { Rest } \\
\text { pain }\end{array}$ & $\begin{array}{l}\text { Raynaud } \\
\text { phenomenon }\end{array}$ \\
\hline $\begin{array}{l}1 \text { D* } \\
\text { F/Us }\end{array}$ & $\begin{array}{l}\text { Smoking - } \\
\text { Improvements - }\end{array}$ & $\begin{array}{l}3 \text { Cases } \\
(37 / 5 \%)\end{array}$ & $\begin{array}{l}2 \text { Cases } \\
(28 / 6 \%)\end{array}$ & $\begin{array}{l}3 \text { Cases } \\
(42 / 9 \%)\end{array}$ & $\begin{array}{l}1 \text { Case } \\
(100 \%)\end{array}$ & $\begin{array}{l}2 \text { Cases } \\
(25 \%)\end{array}$ & $\begin{array}{l}2 \text { Cases } \\
(40 \%)\end{array}$ & $\begin{array}{l}2 \text { Cases } \\
(28 / 6 \%)\end{array}$ & $\begin{array}{l}2 \text { Cases } \\
(100 \%)\end{array}$ \\
\hline $\begin{array}{l}1 \text { D* } \\
\text { F/Us }\end{array}$ & $\begin{array}{l}\text { Smoking - } \\
\text { Improvements } \\
+\end{array}$ & $\begin{array}{l}5 \text { Cases } \\
(62 / 5 \%)\end{array}$ & $\begin{array}{l}5 \text { Cases } \\
(71 / 4 \%)\end{array}$ & $\begin{array}{l}4 \text { Cases } \\
(57 / 1 \%)\end{array}$ & $\begin{array}{l}2 \text { Cases } \\
(66 / 7 \%)\end{array}$ & $\begin{array}{l}3 \text { Cases } \\
(75 \%)\end{array}$ & $\begin{array}{l}3 \text { Cases } \\
(60 \%)\end{array}$ & $\begin{array}{l}5 \text { Cases } \\
(71 / 4 \%)\end{array}$ & $(0 \%)$ \\
\hline $\begin{array}{l}1 \text { D* } \\
\text { F/Us }\end{array}$ & $\begin{array}{l}\text { Smoking + } \\
\text { Improvements - }\end{array}$ & $(0 \%)$ & $(0 \%)$ & $(0 \%)$ & $(0 \%)$ & $(0 \%)$ & $\begin{array}{l}1 \text { Case } \\
(100 \%)\end{array}$ & $(0 \%)$ & $(0 \%)$ \\
\hline $\begin{array}{l}1 D^{*} \\
\text { F/Us }\end{array}$ & $\begin{array}{l}\text { Smoking + } \\
\text { Improvements+ }\end{array}$ & $\begin{array}{l}2 \text { Cases } \\
(100 \%)\end{array}$ & $\begin{array}{l}2 \text { Cases } \\
(100 \%)\end{array}$ & $\begin{array}{l}3 \text { Cases } \\
(100 \%)\end{array}$ & $\begin{array}{l}2 \text { Cases } \\
(100 \%)\end{array}$ & $(0 \%)$ & $(0 \%)$ & $\begin{array}{l}3 \text { Cases } \\
(100 \%)\end{array}$ & $\begin{array}{l}1 \text { Case } \\
(100 \%)\end{array}$ \\
\hline $\begin{array}{l}3 \mathrm{M}^{*} \\
\mathrm{~F} / \mathrm{Us}^{-}\end{array}$ & $\begin{array}{l}\text { Smoking - } \\
\text { Improvements - }\end{array}$ & $\begin{array}{l}3 \text { Cases } \\
(37 / 5 \%)\end{array}$ & $\begin{array}{l}2 \text { Cases } \\
(28 / 6 \%)\end{array}$ & $\begin{array}{l}2 \text { Cases } \\
(25 \%)\end{array}$ & $\begin{array}{l}1 \text { Case } \\
(100 \%)\end{array}$ & $\begin{array}{l}\text { 1 Case } \\
(16 / 7 \%)\end{array}$ & $\begin{array}{l}2 \text { Cases } \\
(25 \%)\end{array}$ & $\begin{array}{l}\text { 1 Case } \\
(12 / 5 \%)\end{array}$ & $\begin{array}{l}2 \text { Cases } \\
(100 \%)\end{array}$ \\
\hline $\begin{array}{l}3 \mathrm{M}^{*} \\
\text { F/Us }\end{array}$ & $\begin{array}{l}\text { Smoking - } \\
\text { Improvements } \\
+\end{array}$ & $\begin{array}{l}5 \text { Cases } \\
(62 / 5 \%)\end{array}$ & $\begin{array}{l}5 \text { Cases } \\
(71 / 4 \%)\end{array}$ & $\begin{array}{l}6 \text { Cases } \\
(75 \%)\end{array}$ & $(0 \%)$ & $\begin{array}{l}5 \text { Cases } \\
(83 / 3 \%)\end{array}$ & $\begin{array}{l}6 \text { Cases } \\
(75 \%)\end{array}$ & $\begin{array}{l}7 \text { Cases } \\
(87 / 5 \%)\end{array}$ & $(0 \%)$ \\
\hline $\begin{array}{l}3 \mathrm{M}^{*} \\
\mathrm{~F} / \mathrm{Us}\end{array}$ & $\begin{array}{l}\text { Smoking + } \\
\text { Improvements - }\end{array}$ & $(0 \%)$ & $(0 \%)$ & $\begin{array}{l}1 \text { Case } \\
(33 / 3 \%)\end{array}$ & $(0 \%)$ & $(0 \%)$ & $\begin{array}{l}1 \text { Case } \\
(50 \%)\end{array}$ & $(0 \%)$ & $(0 \%)$ \\
\hline $\begin{array}{l}3 \mathrm{M}^{*} \\
\mathrm{~F} / \mathrm{Us}\end{array}$ & $\begin{array}{l}\text { Smoking + } \\
\text { Improvements+ }\end{array}$ & $\begin{array}{l}2 \text { Cases } \\
(100 \%)\end{array}$ & $\begin{array}{l}2 \text { Cases } \\
(100 \%)\end{array}$ & $\begin{array}{l}2 \text { Cases } \\
(66 / 7 \%)\end{array}$ & $(0 \%)$ & $(0 \%)$ & $\begin{array}{l}1 \text { Case } \\
(50 \%)\end{array}$ & $\begin{array}{l}2 \text { Cases } \\
(100 \%)\end{array}$ & $(0 \%)$ \\
\hline $\begin{array}{l}6 M^{*} \\
\text { F/Us }\end{array}$ & $\begin{array}{l}\text { Smoking - } \\
\text { Improvements - }\end{array}$ & $\begin{array}{l}3 \text { Cases } \\
(37 / 5 \%)\end{array}$ & $\begin{array}{l}2 \text { Cases } \\
(28 / 6 \%)\end{array}$ & $\begin{array}{l}2 \text { Cases } \\
(25 \%)\end{array}$ & $\begin{array}{l}\text { 1Case } \\
(50 \%)\end{array}$ & $\begin{array}{l}2 \text { Cases } \\
(20 \%)\end{array}$ & $\begin{array}{l}2 \text { Cases } \\
(22 / 2 \%)\end{array}$ & $\begin{array}{l}1 \text { Case } \\
(12 / 5 \%)\end{array}$ & $\begin{array}{l}\text { 1Case } \\
(33 / 3 \%)\end{array}$ \\
\hline $\begin{array}{l}6 \mathrm{M}^{*} \\
\text { F/Us }\end{array}$ & $\begin{array}{l}\text { Smoking - } \\
\text { Improvements } \\
+\end{array}$ & $\begin{array}{l}5 \text { Cases } \\
(62 / 5 \%)\end{array}$ & $\begin{array}{l}5 \text { Cases } \\
(71 / 4 \%)\end{array}$ & $\begin{array}{l}6 \text { Cases } \\
(75 \%)\end{array}$ & $\begin{array}{l}1 \text { Case } \\
(50 \%)\end{array}$ & $\begin{array}{l}\text { 8Cases } \\
(80 \%)\end{array}$ & $\begin{array}{l}7 \text { Cases } \\
(77 / 8 \%)\end{array}$ & $\begin{array}{l}7 \text { Case } \\
(78 / 5 \%)\end{array}$ & $\begin{array}{l}2 \text { Cases } \\
(66 / 7 \%)\end{array}$ \\
\hline $\begin{array}{l}6 M^{*} \\
\text { F/Us }\end{array}$ & $\begin{array}{l}\text { Smoking + } \\
\text { Improvements - }\end{array}$ & $(0 \%)$ & $(0 \%)$ & $(0 \%)$ & $(0 \%)$ & $(0 \%)$ & $(0 \%)$ & $(0 \%)$ & $(0 \%)$ \\
\hline $\begin{array}{l}6 \mathrm{M}^{*} \\
\mathrm{~F} / \mathrm{Us}\end{array}$ & $\begin{array}{l}\text { Smoking + } \\
\text { Improvements+ }\end{array}$ & $\begin{array}{l}\text { 2Cases } \\
(100 \%)\end{array}$ & $\begin{array}{l}2 \text { Cases } \\
(100 \%)\end{array}$ & $\begin{array}{l}3 \text { Cases } \\
(100 \%)\end{array}$ & $\begin{array}{l}1 \text { Case } \\
(100 \%)\end{array}$ & $\begin{array}{l}1 \text { Case } \\
(100 \%)\end{array}$ & $\begin{array}{l}2 \text { Cases } \\
(100 \%)\end{array}$ & $\begin{array}{l}3 \text { Cases } \\
(100 \%)\end{array}$ & $\begin{array}{l}1 \text { Case } \\
(100 \%)\end{array}$ \\
\hline
\end{tabular}

